\title{
Net Exports' Recent (and Surprising?) Contribution to GDP Growth
}

\section{Silvio Contessi}

$\mathrm{G}$ ross domestic product (GDP) in the United States increased at an annual rate of 2.8 percent during the second quarter of 2008. This growth surprised many professional forecasters, who expected a much lower figure because of continuing difficulties in the housing sector and mounting job losses. What accounts for this surprisingly strong performance? The short answer is contributions from international trade, but this answer leads to two more questions. First, how can trade spur growth in the United States when the trade deficit remains historically large relative to GDP (currently about 5 percent)? Second, and more importantly, how likely is it that this growth will persist?

It is important to understand that a country's GDP is the total market value of newly produced goods and services in a given period in that country. GDP can be divided into four main components: consumption expenditures, private business and residential investment, government consumption expenditures and investment, and net exports. The net exports component is the difference between the value of exports and the value of imports; that is, between the value of domestic output sold to foreign citizens and firms and the value of foreign output purchased by U.S. citizens and firms. Each of these four components contributes a certain percentage of the GDP growth rate (see the chart). Quarterly real GDP growth in the chart (black bar) is the sum of the percentage growth rates of each of its components (all other bars). In the second quarter, a large increase in exports contributed 1.54 percentage points, and a large drop in imports contributed 1.39 percentage points; these contributions more than accounted for GDP growth and compensated for the negative impact on growth of investment ( -1.74 percent). ${ }^{1}$

What explains the surprising strength of net exports? Net exports depend positively on foreign demand, but negatively on domestic demand. In the past few months, the U.S. economy has experienced sluggish growth compared with the major trading partners. Thus, the U.S. demand for foreign-produced goods and services stalled, while the demand for U.S.-produced goods and services remained strong. An additional boost to net exports likely came from the depreciation of the dollar against the currencies of major U.S. trading partners in the first half of the year. The net effect has been a significant unexpected export boom during which the trade balance has behaved as a countercyclical variable, in a fashion similar to episodes of sluggish growth.

Answering the second question involves a look at history. So, can we expect this contribution to last? The forecasts of lower world GDP growth as a result of recent financial turmoil and U.S. dollar appreciation over the past few weeks might further curb net exports growth. History also suggests that large contributions of net exports are rare events in the United States. ${ }^{2}$ However, if the demand for U.S. products from abroad weathers the current financial turbulence, the net export component of GDP might continue to be significant.

${ }^{1}$ The contraction of imports contributes positively to GDP growth because imports are subtracted from domestic consumption and investment to account for the fact that these goods and services are consumed but not produced in the United States.

2 The last such instance was in the second and third quarters of 1980, when the contributions of net exports to GDP growth were +4.1 and +3 percent.

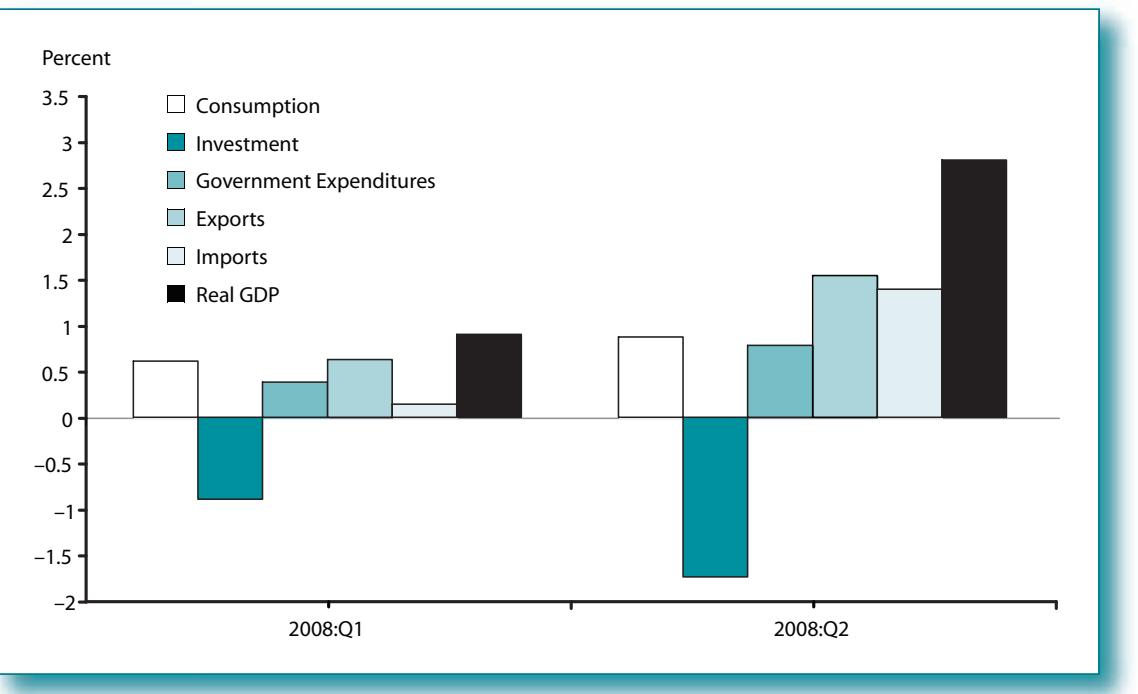

